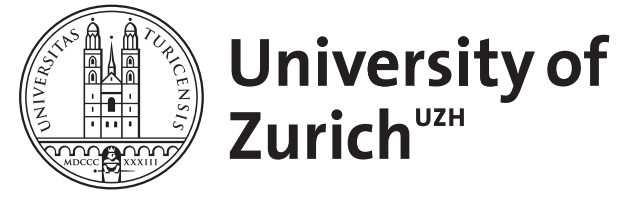
Archive

University of Zurich

University Library

Strickhofstrasse 39

CH-8057 Zurich

www.zora.uzh.ch

Year: 2019

Politics, Capital, and Land Grabs in Punjab, India

Martin, Nicolas

DOI: https://doi.org/10.14324/111.9781787353237

Posted at the Zurich Open Repository and Archive, University of Zurich

ZORA URL: https://doi.org/10.5167/uzh-186609

Book Section

Published Version

Originally published at:

Martin, Nicolas (2019). Politics, Capital, and Land Grabs in Punjab, India. In: Harriss-White, Barbara; Michelutti, Lucia. The Wild East : Criminal Political Economies in South Asia. London: UCLPress, $240-261$

DOI: https://doi.org/10.14324/111.9781787353237 


\section{The Wild East}

Criminal Political Economies in South Asia

Edited by Barbara Harriss-White and Lucia Michelutti 
First published in 2019 by

UCL Press

University College London

Gower Street

London WC1E 6BT

Available to download free: www.uclpress.co.uk

Text (C) Contributors, 2019

Images (C) Contributors, 2019

The authors have asserted their rights under the Copyright, Designs and Patents Act 1988 to be identified as the authors of this work.

A CIP catalogue record for this book is available from The British Library.

This book is published under a Creative Commons 4.0 International license (CC BY 4.0). This license allows you to share, copy, distribute and transmit the work; to adapt the work and to make commercial use of the work providing attribution is made to the authors (but not in any way that suggests that they endorse you or your use of the work). Attribution should include the following information:

Harriss-White, B. and Michelutti, L. (eds). 2019. The Wild East: Criminal Political Economies in South Asia. London: UCL Press. DOI: https://doi.org/10.14324/ 111.9781787353237

Further details about Creative Commons licenses are available at http://creativecommons.org/licenses/

Any third-party material in this book is published under the book's Creative Commons license unless indicated otherwise in the credit line to the material. If you would like to re-use any third-party material not covered by the book's Creative Commons license, you will need to obtain permission directly from the copyright holder.

ISBN: 978-1-78735-325-1 (Hbk)

ISBN: 978-1-78735-324-4 (Pbk)

ISBN: 978-1-78735-323-7 (PDF)

ISBN: 978-1-78735-326-8 (epub)

ISBN: 978-1-78735-327-5 (mobi)

DOI: https://doi.org/10.14324/111.9781787353237 


\section{Contents}

List of figures vii

List of tables viii

List of boxes ix

Notes on contributors $\quad \mathrm{x}$

Acknowledgments xiii

$\begin{array}{ll}\text { Introduction } & 1\end{array}$

Barbara Harriss-White and Lucia Michelutti

1. The criminal economics and politics of black coal in Jharkhand, 2014

Nigel Singh and Barbara Harriss-White

2. Jharia's century-old fire kept ablaze by crime and politics Smita Gupta

3. Sand and the politics of plunder in Tamil Nadu, India

J. Jeyaranjan

4. Himalayan 'hydro-criminality'? Dams, development and politics in Arunachal Pradesh, India

Deepak K. Mishra

5. Crime in the air: spectrum markets and the telecommunications sector in India

Jai Bhatia

6. The inter-state criminal life of sand and oil in North India

Lucia Michelutti

7. 'Red sanders mafia' in South India:

violence, electoral democracy and labour

David Picherit

8. The 'land and real estate mafia', West Bengal, East India Tone K. Sissener 
9. Politics, capital and land grabs in Punjab, India Nicolas Martin

10. The politics of contracting in provincial Bangladesh Arild Engelsen Ruud

11. Putting out the Baldia factory fire:

how the trial of Karachi's industrial capitalism did not happen

Laurent Gayer

Epilogue South Asian criminal economies

Barbara Harriss-White

Appendix Laws alleged or established to have been broken with main offenders

Glossary

Index 


\section{9 \\ Politics, capital and land grabs in Punjab, India}

Nicolas Martin

Engaging critically with the concept of 'political society', this chapter examines the issue of land grabbing in Punjab, and focusses in particular upon the systematic small-scale encroachment on village communal land in a rural Punjab district. It shows how politicians often help farmers to continue occupying village common lands illegally, doing so for electoral gains not necessarily consistent with the logic of 'the market' or of capital. In these cases, politicians seem to be driven by political motives related to electoral calculations rather than solely by financial ones. However, the chapter illustrates how these clientelistic bargains ultimately serve politicians and local elites more than they do those facing the prospect of dispossession.

This chapter offers an ethnographic perspective on land grabs in Punjab, focussing in particular on processes of appropriation of village common lands in rural Punjab: land that should in theory be available for rent to the highest bidder and of which a third is reserved for members of the Scheduled Castes (SCs). I argue that the processes at stake are somewhat different to those emphasised in the growing literature on land grabbing, which focusses on how capitalist accumulation by elite interest groups dispossesses the poor (Whitehead 2008; Adnan 2013; Springer 2013). This literature tends to draw on David Harvey's (2004) notion of accumulation by dispossession and sees land grabs as the result of over-accumulated capital seeking new opportunities for profit. As such, it tends to focus on 'land grabbing' projects that displace thousands of villagers or urban dwellers in order to make space for Special Economic Zones or real estate developments (Adnan 2013; Levien 2011; Sampat 2010; Cross 2014). In this chapter, however, I focus principally on more 
routinised and small-scale processes around encroachment on village common lands in a rural Punjabi district. As Geert De Neve (2015) has argued, "large scale state-led land grabs and mass displacements do not form the only - and perhaps not even the main - form that [primary] accumulation takes in post-reform India'.

Partha Chatterjee (2008) has argued that in post-liberalisation India, politicians are more than ever subject to the hegemony of corporate capital; corporate capital flows rather than electoral mobilisation are increasingly dominating politics, he argues. This is because state-level leaders are competing with each other in order to attract the capital that is necessary to generate economic growth. Corporate capital is gradually pauperising small farmers, small shopkeepers and indigenous communities. Corporate land grabs are one of the many ways this is happening. The concentration of capital also means that large retail and agribusiness companies can put small shopkeepers and small farmers out of business through the use of economies of scale and/or loss-leaders which undercut their prices. Civil society and the judiciary, he argues, are complicit in these processes. The middle classes, as Baviskar (2011) also shows, are tired of the messy reality of electoral politics. For example: the world of politics is the reason why, in their view, urban landscapes are blemished with illegal slums. It is politicians who allow people illegally to occupy land because they obtain votes in exchange for favours. The middle classes want the law to be implemented and the slums to be cleared.

The ad hoc illegal arrangements that prevent squatters from being evicted are the defining characteristic of what Chatterjee calls political society. The sphere of political society is one that operates on the margins of or even outside the law; it is a sphere in which politicians circumvent or break the law in order to appease popular pressures. For Chatterjee, political society has the merit of, for example, providing slum dwellers with a place to live, even though it might not give them the secure legal rights to settle permanently. Were politicians to stick to the letter of the law, slum dwellers would find themselves on the street. As such, he has argued that what he calls the sphere of political society is in fact the principal sphere of activity where resistance to capital and to primitive accumulation takes place. Its main achievement is to prevent the dispossessed from turning into 'dangerous classes' who have nothing to lose and are therefore potentially revolutionary.

In this chapter however, I show how so-called 'political society' can also be complicit in processes of dispossession. The dynamics around land grabbing that I describe here - particularly in the case of village common lands in rural Punjab - bear the imprint of political meddling that 
is informed by the prerogatives of electoral politics rather than, strictly speaking, those of corporate capital. But what this chapter shows - echoing previous work (Martin 2014) - is that the ad hoc clientelistic bargains characteristic of political society can overwhelmingly benefit local elites at the expense of subordinate social groups (Dalits in particular). Moreover it illustrates how the frequently partisan nature of clientelistic interventions means that they further benefit some people at the expense of others. This makes these interventions a cause for conflict and social division, and therefore prevents people from getting together in order to find genuine political solutions to protecting their livelihoods.

The material presented is based on 15 months of ethnographic fieldwork starting in 2013 in villages around a tehsil (sub-district) headquarters within Patiala district, together with some research in the urban tehsil headquarters itself. Much of the material presented is based on interviews with interested parties in a number of land disputes. Given the hotly contested nature of these disputes, and that everyone has their own version of events, I attempt to triangulate people's different versions and points of view. I begin with the broader picture of land grabbing at the state and tehsil level and its relationship with politics, and then move on to examine three case studies of village-common land grabs. In these case studies, politicians often intervene in order to allow supporters to continue possessing village common lands illegally against the logic of the market - much like Chatterjee's politicians who help slum dwellers to continue encroaching upon land that does not belong to them. Were 'the logic of the market' to prevail, this land would go to the highest bidder, and prices for the lease of village common lands would rise significantly. Based on these case studies I try to determine whether it is in fact, as Chatterjee seems to suggest, the poor and lower caste who most benefit from these interventions. Moreover, I examine whether and how these political interventions succeed in preventing the popular unrest that arises out of the dispossession that accompanies the expansion of capital in agriculture.

\section{Shiromani Akali Dal: 'Goonda Raj' and property grabs in Punjab}

During the Shiromani Akali Dal (SAD) party's two terms in power in Punjab, people frequently claimed that it had instituted a reign of goonda raj (thugs) that was just as bad as the one in Bihar under Laloo Yadav Prasad. People - even lifelong Akalis - frequently claimed that corruption 
and criminality in the Punjab was at its worst. Everywhere people told me that tehsildars (revenue collector at the tehsil level), Block Development Officers and police Superintendent House Officers (SHOs) were forced to provide tens of lakh ${ }^{1}$ every month to their local MLA. While this was nothing new - as Robert Wade's (1985) work on the market for public office in India illustrates - people claimed that the extent of these exactions was unprecedented. In the tehsil headquarters, I mostly heard about police exactions. Transporters complained about incessant harassment. People also complained about an SHO nicknamed 'Dabang' because he acted and behaved like a gangster. One local transporter told me that Dabang had asked him to gift him a new motorcycle.

Many informants alleged that in the past corruption in the state happened only at the highest levels. Congress leaders in the state, they claimed, only took money from big business, whereas the Akali government - then in its second term - took money from everyone. The party leadership allegedly had shares in every business in the state, from media outlets to dhabas (roadside restaurants) and bus services to commercial property and industry. Businessmen who refused to pay tribute to the party leadership faced bureaucratic hurdles that caused their businesses to shut down. Police officers harassed transporters by asking them to produce documents that they were unlikely to possess. In the tehsil headquarters, the leader of the Tempu (light transport vehicles) Union described a protection racket whereby the Ministry of Transport issued SAD party membership cards that essentially gave Tempu drivers immunity from police harassment. Cardholders paid INR 150 per month, which was allegedly distributed among local police officers who consequently let them go without checking their documents, and who even let them get away with transporting illegal liquor and drugs. Likewise, a lucrative dhaba might find that if it did not pay tribute, its licence might be withdrawn, or that the police might discourage customers from patronising it by not allowing them to park near it. On a more sinister note, people claimed that the ruling coalition controlled organised crime in the state. The Congress-leaning English-language press in the state often reported on the misdemeanours of Youth Akali Dal (YAD) leaders. The YAD was essentially the strong arm of the SAD and was used to harass opponents, rig elections and, it appears, distribute drugs - principally bhukki (poppy husk) - to purchase votes during elections. A close relative of the Chief Minister controlled the outfit and there were widespread rumours about how he used them as a sena (private army) in his home constituency. Throughout the state YAD youths used their police immunity to settle personal vendettas and to make money through drug trafficking and the 
capture of disputed properties. In 2013-4 one of the main stories dominating the press related to allegations that the head of the YAD was also the lynchpin of the drug trade in Punjab. These allegations came to light after a notorious drug smuggler was captured and interrogated by the police (Sehgal 2014).

Moreover, the SAD politicians stood widely accused of involvement in a variety of land grabbing schemes. One of the SAD's manifesto pledges was to build motorways linking all major cities in Punjab. The process of acquiring land from farmers to build these motorways was murky, and well-connected Akali politicians were widely believed to have amassed significant amounts of money through it. The farmers who had to sell their land to make way for these projects felt cheated. There were stories, for example, about Akali middlemen buying land from farmers at low prices and then reselling it to the government at much higher prices (Vasudeva 2016). Farmers in one village alleged that influential people had spread false rumours to the effect that the middleman in question was going to pay them more than the government would be willing to pay. The rumours even suggested that the government might not give farmers any compensation whatsoever so that it was best to accept the middleman's offer. There were also plenty of stories about land grabs around expanding urban centres. Land prices around cities such as Chandigarh, Ludhiana, Patiala and Bathinda have skyrocketed in recent years. There were stories about moderately prosperous Jat farmers becoming multi-millionaires because their farmland happened to be located in urban peripheries that were being incorporated into the cities. High land values led to a scramble for land located on these peripheries. I also read and heard about a number of cases in which politically influential people were alleged to have somehow managed - using both their influence and bribes - to register portions of village common land in their names and then sell it on to urban developers.

Land values in the tehsil headquarters where I carried out my fieldwork may not have shot up to the same level as in Punjab's major cities, but they also rocketed and were subject to speculation and disputes. The most notorious land grabber here was the president of the Youth Akali Dal, and a village Sarpanch (elected village headman). The young man, whom I will call Gurbachan Singh, started his political career during his college days when he was a kabaddi (a muscular Punjabi contact sport) player. During those days he proved his worth in several fights against rival student groups and eventually defeated rival contenders to the student union leadership. People who knew him from college days told me that he was always getting into fights and that he had already had a 
number of cases filed against him back then. However, the feat that established his notoriety was his capture and subsequent sale of a widow's valuable urban property. The wealthy widow, from the Bania urban trading community, was being harassed by relatives who wanted to gain control over numerous assets, which included a bottling plant, several shops and a couple of urban residential properties. She asked Gurbachan to help her intimidate her relatives and he eventually moved into a wing of her house as her permanent bodyguard. The story goes that it was only after he had gained her full confidence that he turned on her. People claim that he managed to get her to put her large residence in the centre of town in his name; some claim that he did so through persuasion and cunning and others that he did so through threats. Gurbachan eventually took control of the property, kicked the widow out and then used it to host drinking parties before transforming it into a commercial property and selling it off for 3 crore. One of his relatives said that Gurbachan constantly had college girls visiting him there, and even that he started 'providing' girls to politicians and wealthy businessmen.

Speaking with lawyers I learned that while property and land grabs had always happened, the incidence had increased as a result of soaring land prices in the last 10 years. Everywhere people told me that up to 10 years ago property speculation had been a comparatively muted affair; people mostly bought property to farm or to live on, not as a speculative investment. Many farmers told me that they regretted selling land back in the day when an acre of farmland was worth only 2 lakh, and others regretted not buying land when it was still affordable. Now an acre in rural areas is worth up to 40 lakh.

First the rise in land values brought in speculators from as far as Chandigarh. Being outsiders, some such speculators were allegedly duped by locals, in collusion with local government officers, into buying plots without the consent of the actual owners. Government officers in charge of verifying people's identity would fraudulently attest that a person was the owner of a plot and wanted to sell it when the person was in fact just a dummy. The dummy would sell a plot that was not theirs to sell and then share the proceeds with the officers, while the actual owner and the buyer were left to fight protracted legal battles. A young man who had been involved in such a transaction told me that duped buyers rarely got all of their money back, particularly if the kabza group (property grabbing group) was well connected politically.

Today it is more difficult to pull this sort of scam off because the government has introduced more stringent identity checks including the use of Aadhaar (ID) cards and photographs of the parties involved in land 
transactions. While more difficult to carry out, fraud is nevertheless still possible, but according to people in the know it is now increasingly limited to large transactions involving huge sums of money, and for which a tehsildar near retirement might be willing to risk suspension and a protracted legal battle. The way it is now done is that people obtain other people's land records, scan them onto their computers and then, using image manipulation software, replace the owner's name with theirs. They then come to some sort of an agreement with the tehsildar, who will somehow enter the amended title into the system. The person who told me about this, a young man who earned his livelihood from disputed properties, told me that a tehsildar would do this sort of thing only for sums of money above at least 10 crore and that they would also generally only get involved in such a venture if they were close to retirement and thus in any case about to lose their job. He said that if a tehsildar managed to pull this off, his earnings from the fraudulent transaction would far outweigh the potential loss of income due to being suspended as well as the costs of having to fight a protracted legal battle.

In urban areas today the most common type of property scam involves speculators with some political clout - such as Gurbachan from the YAD - investing in disputed properties. Here fraud is not as obvious, but muscle power and political connections are indispensable. Speculators buy disputed properties for a third of their value, sort out the dispute with the help of money and/or force, and then sell them off for their full value. Disputes most commonly arise when a tenant who has proof of long-term residence at a property refuses to pay rent and/ or vacate it. Because of laws protecting tenants it is difficult and in some cases even impossible to evict them. For this reason many owners try to prevent their tenants from accumulating proof of long-term residence, and many owners even try to keep their tenants' electricity and water bills in their own names. In Chandigarh, the state capital, as throughout much of Punjab, many property owners would rather leave their properties vacant than lease them out. Moreover, the issue has gained political salience because many wealthy non-resident Indians (NRIs) who live abroad in the UK, Canada and Australia are unable to regain possession of properties captured by locals - often relatives - in their absence.

The reason why investors in disputed property need some political clout is to be able to evict the people occupying the disputed properties they purchase. While some may accept money to vacate, many others do not. In these cases disputed property speculators need to use force, and for this it appears that some degree of complicity from the police, and the administration more generally, is required. Gurbachan of the YAD 
appears to have this necessary support. Lawyers in the sub-divisional court complex tell me that while Gurbachan has a couple of cases against him dating from his student days, he had no cases registered against him during the Akali Dal's tenure in government; he had the full protection of senior politicians in the party. In his lounge I saw pictures of him with very high-ranking leaders - who his relatives tell me call him on a regular basis - and with the local MLA and Minister, whom he regularly meets. Among the reasons why Gurbachan had political support were that he helped mobilise crowds for SAD rallies, he intimidated and harassed regime opponents and he captured ballot booths during local elections.

\section{Rural land grabs}

In many of the above cases, politicians and their intermediaries and cronies were principally involved in land grabs for financial gain. The logic of these land grabs was that of capital. However in the case of village common lands, politicians facilitated small-scale land grabbing principally for electoral gain. The logic of these land grabs was therefore closer to that of political society: the sphere in which, according to Chatterjee, resistance to capital and to primitive accumulation takes place.

The issue of control over village common lands needs to be understood within a rural context where politically-connected farmers, often associated with the state government, controlled village politics and were able to appropriate the greater bulk of government resources-including common lands - in their villages (see Martin 2015). They often did so at the expense of their village rivals aligned with opposition parties but also at the expense of the Dalits (or Scheduled Castes - SCs). As a result, control over village common lands was a highly divisive issue. And if political society and patronage benefitted anyone in this context it wasn't the Dalits, those who formed the most disadvantaged sector of Punjab society.

Despite their rising independence and assertiveness, members of the SCs still do not wield significant power at state or village level in Punjab. SCs may have become less submissive and they may be flocking away from Jat-dominated Sikh institutions and to deras; ${ }^{1}$ they may be pressing for a greater share of government resources (Jodhka and Prakash 2003) and they may be avoiding agricultural work under the command of exacting, dominant-caste Jat farmers (Gupta 2005). Yet my observations suggest that because they remain politically dependent on the dominant-caste Jats who control panchayats (village councils) they continue to be deprived of a wide variety of government entitlements. 
Most notably, politically connected Jats continue to control village common lands and also land that should technically be managed by Dalit cooperatives. The latter is known as Nazool land: land that once belonged predominantly to Muslim evacuees who left for Pakistan at partition and which was meant to be handed over to Dalit cooperatives. Jat-caste farmers often illegally occupy Nazool land. Farmers with political connections - usually in the ruling party - have likewise captured the larger share of shamlaat zameen (village common land), including the share of it reserved for Dalits. Village common land belongs to villages as a whole, and village panchayats are meant to lease it out to the highest bidder in open auctions and on a rotational yearly basis. Decades ago, this land used to be used for grazing livestock. However, the growing demand for agricultural land has meant that it has gradually been turned over to growing Punjab's staple crops: wheat and rice. The landless have, in the process, been deprived of land to graze their livestock, and fewer now own livestock (see Jodhka 2014).

Some villages have almost no common land, but others can have hundreds of acres of it. The money generated from the lease of this land is meant to go to panchayats to be used for village development projects. Villages with lots of common land should in theory generate significant income from it. A village with 200 acres should, for example, be able to generate up to INR 8 million per year. Furthermore, one-third of village common land is reserved for Dalits. This should in theory allow them to grow some cash crops or fodder for cattle. It should also provide them with opportunities to gather firewood, and also - if farmers deny them access to their fields - with a place to go to the toilet.

In practice however village common lands have tended to generate little income for villages, and both ordinary farmers and Dalits are routinely deprived of their rightful share in it. In some villages that I visited, village common land tended to generate little income because much of it was under the kabza (capture) of both rich and poor Jat farmers. In some cases the land had been under the kabza of a single family for decades and generated no income for villages at all. Such families felt entitled to the land because they had worked hard to improve it: levelling sand dunes, clearing scrub forest, and investing in tube wells for irrigation. In other cases it generated little village income because politically influential farmers were paying far below market prices to lease the land. I found that in a number of villages people were paying no more than INR 8,000 per acre annually while prices for the lease of irrigated agricultural land in Malwa had reached an unprecedented INR 40,000. Moreover I found out that a black market in village common land had developed in at least 
one village. Village common land was being traded but at rates far below the market rate for private agricultural land since it was not possible to obtain legal ownership over it.

It was often the case that panchayats, in collusion with panchayat secretaries and senior politicians, failed to hold the stipulated kulli boli (open auctions) for the lease of village common lands. Sarpanches and their allies were able to encroach upon village common lands by holding these 'auctions' in the privacy of their homes without publicly notifying villagers. In practice this meant that only Sarpanches and their supporters were given the chance to make a bid. Dalits, but also farmers from rival political factions often found that they were denied the opportunity to lease village land. Senior politicians were often complicit to the extent that they failed to take administrative measures to redress the situation, particularly when it benefitted loyal party workers and supporters. As will be illustrated below, they also sometimes actively tried to prevent encroachers from being evicted.

In order to get around the provision that a third of the land was reserved for Dalits, Sarpanches used dummy candidates to make their bids. The dummies were often their own farm servants. Thus, on paper the land was allotted to a Dalit, but in practice it was that Dalit's master who actually cultivated the land. ${ }^{2}$ Dalits did not always protest because they did not have the tools to farm with and because panchayats had failed to equip village lands with tube wells. This meant that only farmers who owned tube wells on land adjacent to particular plots of village common land could actually cultivate it. During my fieldwork, Dalits in some villages that I visited blamed the government for failing to provide them with the equipment necessary to farm, and for failing to invest in tube wells that would allow them to irrigate plots of village land.

During fieldwork in 2013-4 many Sarpanches were involved in lengthy court cases aiming to clear village common lands of encroachers. The ostensible aim of this legal procedure was to boost village revenues. The government had an interest in the process too, because roughly a third of the income generated was to go into state coffers. These cases were highly contested. The left-leaning Dakonda farmers' union, for example, strongly opposed this clearance because it risked depriving farmers of land that they had improved and cultivated for decades - some since Independence. It also opposed clearing village common lands of encroachers on the grounds that the rule of the market would dramatically raise the price for leasing village common land and would put it beyond the reach of ordinary small farmers who could barely make a living. Village-level Dakonda Union leaders also alleged 
that the government was making way for corporate agriculture, although the extent to which this was the case was unclear. Pointing to a perhaps more immediate threat, they asserted that the policy did not necessarily do away with the malpractices associated with village common land and that it was frequently implemented in ways that harmed the interests of those in the political opposition. The following three cases illustrate some of these dynamics, and also how politicians often protected some encroachers at the expense of others and thus ultimately hampered the emergence of a workable joint solution to the issue of control over village common lands.

\section{Case I: Daroli}

The case of Daroli illustrates how the issue of control over village common lands was a source of conflict and acrimony, and also demonstrates the role of politicians in exacerbating these conflicts and acrimonies. It illustrates how politicians, with their ad hoc interventions, could fail to effectively protect people from dispossession.

In this village, Kuldip Singh Kombhoz initiated the process of clearing village common land of encroachers when he was Sarpanch from 2008-13. He claimed to want to improve the 60 acres of common land in order to increase village revenues for development. However, his detractors claimed that he merely wanted to evict his political rivals from the land and redistribute it to his supporters. A local newspaper even reported that Kuldip had cleared village common lands of encroachers merely to replace them with his friends, relatives and supporters. $\mathrm{He}$ denied this, claiming that the newspaper in question had fabricated the story. They had purportedly blackmailed him by telling them that unless he paid them some money they would fabricate a negative story about him. Whatever the case may be, he was able to evict the encroachers who had taken hold of 36 acres of village common land in 2012 . He was proud of his achievement, and claimed that thanks to his efforts the village had earned INR 1.2 million from its lands.

His policy had, however, proven to be highly divisive and in 2014 villagers were reluctant to place any bids on village common land, because doing so risked antagonising those who had traditionally cultivated particular plots of land but who had been evicted. The Dakonda Kisan Union had become involved on behalf of the farmers and its members had clashed with the police when the latter had come to remove the farmers from the land they were occupying. 
Kuldip Singh claimed that the Minister for Panchayats and Rural Development had initially supported his initiative, but when the minister had seen that it might cost him party votes he had not only backtracked but also turned against him. He claimed that the minister had first started supporting the farmers by helping them obtain court stays that allowed some of them to remain in possession of the land for an extra year. He also claimed that the minister was in all likelihood responsible for the fact that the construction of an electrical line through the village common lands had been halted. Without electricity he would not be able to install tube wells on the land and village revenues from village common lands would not rise. This, he explained, served the interests of the farmers because they would be able to continue renting village common lands at the lower rate for unirrigated land. He also claimed that the minister had once told the farmers that if he - Kuldip - continued to insist on the issue that they would give him a good beating. The minister had apparently said this during one of his meetings with his constituents at his mansion outside Patiala. Kuldip even claimed that the minister had encouraged the farmers to fabricate a case against him and supported them in the endeavour. So he was taken to court for allegedly building a part of his house on village common land. The case was spurious, and it failed, but it worsened village level animosities.

Balvinder Singh, the owner of four acres of land, confirmed that the minister had supported the 'encroaching' farmers, and helped some of them obtain temporary stay orders from the court. He and his parents and grandparents before him had cultivated five acres of village common. His grandfather had cleared the land of tibbas (sandy hillocks) and made the land cultivable. The land was irrigated with water from a polluted river that ran past the village, but he claimed that the dirt in the water meant that he did not have to use much fertiliser to obtain good crops. He rejected Kuldip's claim to the effect that he was an encroacher. He said that he had always paid to cultivate the land but that he could not provide full proof of this because Kuldip, while he was Sarpanch, had never provided him with receipts for his payments. He had relatives who were close to the minister; they had got the minster somehow to intervene in the court case on his behalf, and he had obtained a stay order. However the minister's intervention was merely ad hoc and temporary and he was eventually forced to vacate the land and forgo half of his income.

The issue of village common land polarised the village, and those who didn't want to get embroiled in the conflict were reluctant to place their bids on land that others had improved and cultivated all their lives. The current Sarpanch was an SC who had obtained the post because it 
was reserved. He told me that he did not want to get involved in this contentious issue, and that as a Chamar he could not afford to antagonise anyone. It was a highly contentious issue because people's incomes - and some people's very subsistence - depended upon the village common land that they had encroached upon. One Jat whom we interviewed told me that the politicking of village leaders had ruined him. He had cultivated some 10 acres of village common land his entire life and now because of Kuldip he had almost nothing left. However, he also blamed the ruling Akali Dal for letting it happen and claimed that the minister's efforts to help them obtain a stay order were not particularly helpful: that he had made a token gesture out of political expediency. The Jat owned only one and a half acres, which was not enough to live from. On top of that he was unable to work due to back problems and did not know how he would make a living.

\section{Case II: Tullewal}

The case of Tullewal likewise illustrates how the most senior local Akali politician ended up supporting encroachers because he feared the political fallout that would result from evicting those illegally encroaching upon village common lands. Again, however, he ended up supporting one faction at the expense of another and thus contributed to further dividing the village into two irreconcilable camps. As in Daroli, he exacerbated village factional rivalries and thereby contributed to preventing villagers from finding a joint solution regarding the control and use of village common lands.

Harpal, the village Sarpanch until 2013, had initiated a judicial process against encroachers and had managed to clear some 56 (of roughly 90 total) acres of village common land. He had also managed to obtain six tube wells from the government to irrigate some of it. The process had, Harpal claimed, been expedited by the Minister of Agriculture and Rural Development. Harpal's chief village rivals, Malvinder and his supporters, had allegedly placed spurious corruption cases against him in response, because his actions threatened them. Malvinder had captured four acres of village common land and Sukhvinder - an ally and farmer union leader - had allegedly captured 13 acres. Despite his efforts however, Harpal was not able to have either evicted because the minister had prevented the police from doing so despite court orders. He claimed that the minister was 'playing politics' because he feared that by evicting them he would lose votes. He had become 'frightened' when he had seen that 
the farmers' union had gathered a large number of people in protest; he worried that it would cost him not only the support of the Tullewal villagers but also that of the broader public, because news of the protests had come out in the newspapers.

Partly as a result of all the unrest caused by the clearing of the village common lands, Harpal lost the 2013 panchayat elections to Malvinder, his chief rival. Harpal had been very close to the minister, and he had many pictures to prove it, but the relationship had somewhat soured after the minister had started supporting the encroachers. Later, after Harpal had lost the 2013 elections, the minister started collaborating with Malvinder - and was doing so even though Malvinder was not a loyal Akali. He did so, according to Harpal, because that was allegedly the way of politicians: they knew no loyalties, and all they cared about were votes. Harpal, and five others who were there on one of the occasions when I interviewed him, told me that Malvinder had held the latest auction for village common land in the secrecy of his home. He said that Malvinder had bribed the Block Development Officer in order to do so, and that he had the support of the local Akali Minister. As a result, none of those present had been given the chance to place their bids and obtain some land. On the other hand, Malvinder and his friends had all obtained land and had secretly agreed to ensure that the leasing price for any plot should not rise above INR 20,000. Harpal complained that the panchayat should in reality be obtaining over INR 35,000 per acre for that land because almost all of it was now irrigated with the tube wells he had obtained from the government. Sukhvinder, one of Malvinder's allies, seemed to give this latter claim some credence when he told me that he was paying INR 22,000 per acre. Moreover, Harpal claimed that Malvinder was technically banned from renting village common land because he was a defaulter: he had, over several years, failed to pay a single cent for the four acres of village common land that he had cultivated. In order to circumvent this hurdle, Malvinder had entered the name of his Dalit farm servant as the new tenant for that land.

Sukhvinder and Malvinder obviously had an entirely different perspective on the issue. Both accused Harpal of initiating the clearance of village common lands through the courts - not because he was interested in augmenting village revenues but rather because he bore a grudge against them as a result of their longstanding political rivalry at village level. They also suggested that if he was interested in increasing village revenues it was merely in order to be able to steal more from the panchayat. Malvinder accused Harpal of gross corruption, and had placed a case against him for embezzling over INR 400,000 during the 
construction of a stretch of road and some associated drains. Malvinder said that Harpal had stolen far more than that during his tenure but that he did not have the evidence necessary to take him to court for all of the corruption cases. The case against Harpal was successful at the tehsil level, and he was ordered to pay a INR 355,000 fine. But Harpal subsequently placed an appeal and was eventually exonerated.

\section{Case III: Fatehpur}

The case of Fatehpur likewise illustrates the socially divisive nature of political interventions in the issue of village common lands, and most clearly illustrates the extent to which the complicity of politicians could benefit the few at the expense of the rest. The case is different to those of Daroli and Tullewal to the extent that in Fatehpur the clearance of village common lands was complete by the time I finished fieldwork in 2014. As a result of the implementation of public auctions, village common lands had become subject to market values and leasing them had become more expensive. This, as the Dakonda farmers' union leaders had feared, meant that poorer farmers ceased to be able to lease village common land.

Legal disputes for control over village common land in Fatehpur started in 1986 when Nirmal Singh took Khem Singh to court for capturing 86 of a total of 180 acres of village common land. Both Khem Singh's rivals and his supporters told me that Khem Singh's family had controlled that land for several decades thanks to their political connections, and had worked to improve it. Khem Singh and his two brothers only owned four acres of land, and it was widely agreed that they had been able to build a large house with all the modern domestic appliances and to purchase two new four-wheel drive cars and also a new tractor thanks to their control over those 86 acres of village common land.

Khem Singh had been involved in court cases against Nirmal Singh and other rivals over this land for over three decades. Nirmal Singh, and a friend of his, eventually landed in jail for the murder of a woman who he had purchased some land from. His successor as faction leader, Naib Singh, alleged that Nirmal Singh was innocent and that it was Khem Singh who had set him up with the help of his police and political contacts. Despite the court cases against him, Khem Singh's family had been able to continue cultivating at least some of the village common land and in 2013 he and others told me that he was renting 30 acres at INR 20,000 per acre. 
Aligned with the ruling SAD, Khem Singh won the 2013 local elections. The previous Sarpanch had been a Dalit Mazhbi Sikh - aligned with the Congress party and with the Nirmal Singh faction in the village - who had not been able to complete his term because Khem Singh who had close relations with the local Akali leader had had him suspended. The Dalit Sarpanch had apparently performed the auction for the village common land in the privacy of an allied Jat farmer's home without advising anyone but his own allies, and on a Sunday when none of the concerned block-level officials could attend. This blatant and blundering act - in the words of his own allies - got him suspended, and Khem Singh finished his term for him before going on to win the 2013 local elections. While not entirely denying that there had been irregularities in that auction, one member of Nirmal Singh's faction said that the only reason why the Sarpanch was suspended was that he and his supporters were affiliated with the Congress party at the time of an Akali government. He claimed that there was always some 'little irregularity' in village common land auctions, but that the Akalis only turned it into an issue when it was members of the opposition who were responsible for these irregularities.

Once in power, Khem Singh was said to have performed village common land auctions according to the rules, and everyone who wanted to had managed to place their bids, but the cost of renting village common land shot up dramatically. One of Khem Singh's supporters, an impoverished Jat who collected and sold milk, told me that he used to rent three acres of village common land but that he could no longer afford to do so. He had rented the land at INR 10,000 per acre, but the price had shot up to INR 45,000. Naib Singh cited the same numbers and told me that although he still cultivated village common land it had become too risky for him to continue to do so. If crops failed for some reason, he would make a loss. Various people told me that the rental price had risen so much that only the richest farmers could now cultivate village common land. One person told me that roughly since 2012 , only 20 people cultivated village common land: all of them wealthy farmers. Prior to 2012, however, over 40 people had cultivated it. Nevertheless, Khem Singh paid only INR 20,000 per acre while everyone else was paying INR 40-45,000 per acre. One of his supporters said that the reason for this was that the land in question did not have any tube wells on it. However, Naib Singh told me that the land did not have any tube wells because Khem Singh had intentionally avoided placing any on that particular area of land in order to be able to lease it at half the rate. But in fact, the land was irrigated because Khem Singh possessed two tube wells on his own four adjacent acres, and used them to irrigate those 30 acres. One person even alleged that Khem Singh was, in 
fact, not paying any rent at all for 10 of those 30 acres, but there was - as with many of these allegations - no way for me to confirm this.

Some people also had mixed views about what Khem Singh had done with the money that was flowing into the panchayat's coffers. The village was earning roughly INR 4.5 million from its village common lands, and Khem Singh had used this money to fix all the village gutters and pave its alleyways with cement bricks. However, many of his Congress party opponents alleged that he was appropriating a share of the new revenue stream. They believed that even more works could have been carried out in that village with those revenues and that Khem Singh was undoubtedly taking a share. They claimed, however, that it was difficult for them to confirm their suspicions because Khem Singh kept the village panchayat records in his home. Local government regulations stipulate that these records should be freely available for public scrutiny; in practice Sarpanches tend to keep them in the secrecy of their homes. Moreover, they claimed that no one was willing to place a Right to Information (RTI) request because people believed it would be futile and potentially dangerous. Futile because the Akali government would botch any investigation against a party loyalist; dangerous because the Akali government might help Khem Singh place fabricated and spurious police charges against those seeking to investigate him (see Martin 2015, 2018).

Last but not least, there was further cause for acrimony because Khem Singh had allotted some village common land for subsidised government housing plots. This had given rise to yet another legal dispute because the land granted was almost entirely cultivated by Khem Singh's opponents. These opponents alleged that Khem Singh had purposefully sought to harm their interests. They told me that they had proposed an alternative, 'better place' for those plots, but that Khem had insisted on putting them on land that they cultivated. In 2014, the plots were already demarcated and 11 persons had moved in and built houses. However, many people - mostly landless Dalits - were hesitant to move in and build their houses, saying that the legal dispute about the placement of those plots meant that their legal status was unclear. Those who had already moved in told me that they had not yet been granted land titles, and that without land titles they could not hook up to the electricity supply. Moreover, they complained that they could not defecate in adjacent fields because those fields belonged to the very Jats who had issued the legal challenge against those five marla plots. ${ }^{3}$ One Chamar woman told me that the Jats had hurled abuse at her and threatened to beat her and her husband up if they ever dared make use of their fields again. 


\section{Conclusions}

The first thing to emerge from these case studies is that political society may protect some people from the expansion of capital, but not all. The context described is one in which politicians bend and break the law, often - but not always - for members of an already comparatively privileged class. Many of those for whom they bend, break or simply fail to ensure the application of the law are even very privileged. In this process, the most disadvantaged - namely the Dalits - have been and continue to be deprived of their lawful share of village common land. The argument could nevertheless be made that these case studies illustrate how the operations of political society do, nevertheless, put the brakes on processes of accumulation by dispossession. Besides large-scale farmers, a number of smaller farmers were seemingly able to sustain their livelihoods thanks to the fact that politicians didn't press the administration to apply the law and evict encroachers.

As members of the Dakonda farmer's union warned, and as villagers in Khanpur confirmed, allowing open and market-based auctions for village common lands placed village common lands beyond the reach of all except the richest farmers. In other words, allowing the market to rule would contribute to the gradual expansion of capital and to the dispossession of petty capitalists.

The above case studies certainly suggest that there is some truth to the idea that the ad hoc arrangements of political society put a break on dispossession. However because of the frequently partisan nature of how this is done, it is a divisive practice that prevents farmers from getting together to find a solution to the issue of village common lands. In all of the three cases above, political interventions had benefitted one faction at the expense of another, and had contributed to exacerbating existing rivalries.

As I have argued elsewhere (Martin 2018), the Akali Dal governed in a highly partisan manner. It protected supporters, regardless of whether or not they were corrupt, and it harassed political opponents on the basis of both real and fabricated corruption charges and allegations. Thus in the case of Tullewal described above, the minister allegedly intervened on Harpal's behalf to help him escape corruption charges. As already noted in the first section, accusations to the effect that the government supported its corrupt intermediaries were common. Gurbachan - the YAD thug and Sarpanch discussed above - was, for example, widely believed to have full police cover for his activities. This became crystal clear to me when I saw him capture a polling booth in full view of the 
police during the 2013 local elections. The police did nothing as he and his comrades barred Congress supporters' entry into the polling station and then attacked them with sticks, swords and stones.

Other cases were perhaps less clear but accusations at the very least point to the fact that people believed that Akalis had impunity. In Fatehpur, for example, people believed that it would be futile to investigate Khem Singh for corruption because the administration would not be responsive. Some even feared physical harassment at the hands of either thugs or the police. When on the other hand people were opposed to the minister or to his party, they were harassed. In Gurbachan's village, Congress party opponents who tried to resist Gurbachan's capture of the polling booth ended up facing attempted murder charges. In Daroli, when Kuldip obstinately pursued the clearing of village common lands, the minister allegedly helped manufacture a spurious case against him.

As I have argued elsewhere (Martin 2018) such partisan political interventions in village affairs exacerbated village-level disputes and animosities. These interventions had the effect of fuelling and escalating disputes that may not have otherwise flared up. Everywhere, people told me that it was politicians and political parties that caused people to fight, and that made village life unbearable. An opposition Congress party worker put it this way:

Politicians don't resolve disputes; they aggravate them. If someone asks me to help resolve some dispute, I'll approach the opposing party and try to engineer a samjhota (compromise). An Akali party worker will, on the other hand, use his power to get the police to bring charges against the opposing party and, as a consequence, the parties will never speak to each other again.

What consequence did political meddling have for farmers' prospects of finding a workable solution to the issue of control over village common lands? In this context, the effect of the ad hoc political meddling - characteristic of political society - was to keep farmers fighting each other and trying to kick each other off village common lands, not to ensure that all of their livelihoods were shielded from the expansion of capital. Lack of unity meant that - in the end - farmers were sometimes unable to resist the clearing of village common lands. The process had been completed in Khanpur and the Akali minister's attempts to obtain a stay order and to stop the police from evicting encroachers in Daroli was merely a stopgap measure. 
Finally, I would like to suggest that there is a sense in which these ad hoc measures to facilitate illegal encroachment were in fact ultimately exploitative. Both politicians and Sarpanches could exploit the legal uncertainty of these arrangements for electoral gain. The case of the five marla housing plots in Fatehpur clearly illustrates how this worked, and how the precariousness of extra-legal arrangements could serve to create semi-captive vote-banks. Khem Singh had granted people land over which there was a legal dispute, meaning that the possibility of putting those plots in their name was uncertain. Members of the opposition Congress party faction had mounted a legal challenge to keep control of that particular area of village common land because they had been cultivating it for decades. A number of villagers asserted that Khem Singh - in collusion with the MLA - had purposely put the prospective plot owners in this precarious position, claiming that if he had given them secure land titles he would have had no guarantee that they would vote for him the next time round. As it was, however, Khem Singh could claim that it was his opponents who were preventing the SCs from getting the housing plots, and that their only chance to secure their property titles was by rallying behind him.

A similar dynamic seemed to underwrite the capture of village common lands. People aligned with the local Akali minister and his local allies were more likely to be able to continue illegally controlling and cultivating village common lands than were members of the political opposition. The latter were the ones most frequently evicted from village common lands while those with government support seemed able to maintain their grip on village common lands even when they paid little or nothing to cultivate them.

However, their hold over that land was contingent upon the continued good will of Akali politicians and upon the latter's willingness to prevent the Ministry of Panchayats from taking action against them, and even upon Akali politicians' willingness to hold the police back when courts had ordered their eviction. Were they to suddenly start opposing the SAD by joining - for example - the Congress party, their semi-legal hold over village common lands would likely be subject to sudden legal scrutiny. In other words, the legal precariousness that is an intrinsic part of informal arrangements in political society allowed politicians to hold citizens to account for their political loyalties and even arguably for their electoral choices.

So even if politicians did sometimes help to put a temporary brake on accumulation by dispossession through ad hoc and clientelistic 
favours, they were at least partly responsible for the lack of an adequate solution to the problem of village common lands. Ultimately however it is important to keep in mind that they were crucial parties to processes of accumulation by dispossession. The literature on land grabs cited above shows that in Punjab - as in other states in India - it is politicians who are brokering land deals for local and international corporations. This is particularly true in the context of post-liberalisation India, where - as Kanchan Chandra (2015) has argued - state-level political corruption revolves around brokering land deals for big money. As indicated at the outset, it is also often politicians themselves who are involved in acquiring land - through occasionally dubious means - for their own purposes.

\section{Notes}

1. Frequently non-denominational religious institutions centred around holy men.

2. This, and the capture of Nazool land, led to the emergence in 2013 of a movement called 'Zameen Prapti Sangarsh Committee' in the district of Sangrur. The movement seeks to ensure that Dalits obtain their rightful share of village common land and that Nazool land is handed back to them. More ambitiously, the movement also hopes to reduce the ceiling on landownership to 10 acres.

3. One marla is roughly the equivalent of 25 square metres, but marlas have been defined differently in different periods and regions of the subcontinent.

\section{References}

Adnan, S. 2013. 'Land Grabs and Primitive Accumulation in Deltaic Bangladesh: Interactions between Neoliberal Globalization, State Interventions, Power Relations and Peasant Resistance', The Journal of Peasant Studies 40(1): 87-128.

Baviskar, A. 2011. 'Cows, Cars and Cycle-rickshaws: Bourgeois Environmentalists and the Battle for Delhi's Streets'. In Elite and Everyman: The Cultural Politics of the Indian Middle Classes, edited by A. Baviskar and R. Ray, 391-418. London and New Delhi: Routledge.

Chandra, K. 2015. 'The New Indian State: The Relocation of Patronage in the Post-Liberalisation Economy', Economic and Political Weekly 50(41): 46-58.

Chatterjee, P. 2008. 'Democracy and Economic Transformation in India', Economic and Political Weekly 43(16): 53-62.

Cross, J. 2014. Dream Zones: Anticipating Capitalism and Development in India. London: Pluto Press.

De Neve, G. 2015. 'Predatory Property: Urban Land Acquisition, Housing and Class Formation in Tiruppur, South India', Journal of South Asian Development 10(3): 345-68.

Gupta, D. 2005. 'Whither the Indian Village: Culture and Agriculture in "Rural" India', Economic and Political Weekly 40(8): 751-8.

Harvey, D. 2004. 'The "New Imperialism”: Accumulation by Dispossession', Actuel Marx 1: 71-90.

Jodhka, S.S. 2014. 'Emergent Ruralities: Revisiting Village Life and Agrarian Change in Haryana', Economic and Political Weekly 49(26-7): 5-17.

Jodhka, S.S. and L. Prakash. 2003. 'Caste Tensions in Punjab: Talhan and Beyond', Economic and Political Weekly 38(28): 2923-6.

Levien, M. 2011. 'Special Economic Zones and Accumulation by Dispossession in India', Journal of Agrarian Change 11(4): 454-83.

Martin, N. 2014. 'The Dark Side of Political Society: Patronage and the Reproduction of Social Inequality', Journal of Agrarian Change 14(3): 419-34. 
Martin, N. 2015. 'Rural Elites and the Limits of Scheduled Caste Assertiveness in Rural Malwa, Punjab', Economic and Political Weekly 50(52): 37-44.

Martin, N. 2018. 'Corruption and Factionalism in Contemporary Punjab: An Ethnographic Account from Rural Malwa', Modern Asian Studies 52(3): 942-70.

Sampat, P. 2010. 'Special Economic Zones in India: Reconfiguring Displacement in a Neoliberal Order?' City and Society 22(2): 166-82.

Sehgal, M. 2014. 'Den of Drugs: How Punjab Politicos are Linked to Rs 700-crore Drug Racket', India Today, January 12. https://www.indiatoday.in/india/north/story/punjab-politiciansin-dock-for-alleged-connections-to-drug-lords-176476-2014-01-12 (accessed 14 May 2019).

Springer, S. 2013. 'Violent Accumulation: A Postanarchist Critique of Property, Dispossession, and the State of Exception in Neoliberalizing Cambodia', Annals of the Association of American Geographers 103(3): 608-26.

Vasudeva, R. 2016. 'Hoshiarpur land scam: Politically connected dealers bought land at throwaway prices', Hindustan Times, 18 June. https://www.hindustantimes.com/punjab/ hoshiarpur-land-scam-politically-connected-dealers-bought-land-at-throwaway-prices/storyDww0uUe4UeUIC0y8lP8tFI.html.

Wade, R. 1985. 'The Market for Public Office: Why the Indian State Is Not Better at Development', World Development 13(4): 467-97.

Whitehead, J. 2008. 'Rent Gaps, Revanchism and Regimes of Accumulation in Mumbai', Anthropologica 50(2): 269-82. 